Bangladesh J. Sci. Res. 28(1): 43-50, 2015 (June)

\title{
EFFECTS OF ALTERNATE WATER SOURCE ON THE YIELD AND NUTRIENT COMPOSITION OF STEM AMARANTH IN THE COASTAL REGION OF BANGLADESH
}

\author{
Farzana Yasmin, Sayma Khanom* and Shahid Akhtar Hossain \\ Department of Soil, Water and Environment, University of Dhaka, \\ Dhaka-1000, Bangladesh
}

\begin{abstract}
A field experiment was conducted in Khulna district to evaluate the growth and nutrient composition on stem Amaranth by irrigating with different water sources. Water that has been used as treatment are saline water, $T_{1}$ and treated water, $T_{2}$ (water from a project called Managed Aquifer Recharge (MAR)). A field condition was also included, $\mathrm{T}_{0}$ (control). All the growth parameters of the crop were significantly improved for treated water. Whereas, N, P, and K uptake (3.54, 39.56 and $564.42 \mathrm{~kg} / \mathrm{ha}$, respectively) were increased and S was decreased (48.76 kg/ha) for treated water $\left(\mathrm{T}_{2}\right)$ compared to control $\left(\mathrm{T}_{0}\right)$. Carbohydrate and total dietary fiber (TDF) is increased (6.09 and $6.87 \mathrm{~g} / 100 \mathrm{~g}$ ) while protein, fat, ash and energy in the leaf of stem Amaranth is decreased (3.16, 0.46, $3.26 \mathrm{~g} / 100 \mathrm{~g}$ and $54.94 \mathrm{Kcal} / 100 \mathrm{~g}$ respectively) by irrigating with $\mathrm{T}_{2}$ water. Moreover, carbohydrate content is increased ( $3.55 \mathrm{~g} / 100 \mathrm{~g}$ ) in treated water $\left(\mathrm{T}_{2}\right)$ but protein, fat, ash, TDF and energy in the stem of stem Amaranth is decreased. EC, $\mathrm{pH}, \mathrm{Na}, \mathrm{K}, \mathrm{Ca}$ and $\mathrm{Mg}$ of the soil were decreased markedly by applying treated water $\left(\mathrm{T}_{2}\right)$ and other nutrients present in soil also varies. From the study, it can be concluded that the best alternate source of water for irrigation is MAR water $\left(T_{2}\right)$ which can improve plant nutrient content and uptake and soil nutrient status.
\end{abstract}

Key words: Managed Aquifer Recharge, Nutrient composition, Stem amaranth

\section{Introduction}

Millions of hectares of land throughout the world are too saline to produce economic crop and more land is becoming non-productive each year because of salt accumulation. The coastal region of Bangladesh covers almost $29,000 \mathrm{~km}^{2}$ or about $20 \%$ of the country (Karim et al. 1982).

The adverse effects of saline water intrusion will be significant on coastal agriculture and the availability of fresh water for public and industrial water supply. The impact of salinity on crop production as well as on aquatic environment is well documented (Karim et al. 1990). The advancement of the saline front in the Khulna region is a matter of concern. Irrigating land with saline water is building up salt crust over the cultivable land which decreasing the net production of land. Karim et al. (1990) reported that the general pattern of soil salinity build-up has been observed in about 0.833 million hectares of the arable lands in 64 coastal thanas of thirteen districts. About $0.282,0.297,0.191,0.450$ and 0.087 million hectares of lands are affected by very slight, slight, moderate, strong and very strong salinity respectively (Haque 2006). This varying salinity levels

*Corresponding author: <sayma_swedu@yahoo.com>. 
have been affecting our cropping pattern and causing yield reduction. In some places nutritional lacking or problems of consuming more specific minerals by the people due to salinity is causing health problems. Bangladesh is a poor country with a large number of population. There are many varieties of leafy vegetables (commonly known as shak) and 25 varieties of non-leafy vegetables in Bangladesh. Salinity in soil restricts the production of many of them. If dark leafy green vegetables can be grown in saline areas, it can supply proper nutrition to the poor and rural people. Keeping this view in mind, the present study was undertaken to observe the visible differences and nutritional composition of vegetable for irrigation with saline and non-saline water and also to identify whether it is possible to grow salt sensitive crops particularly vegetables by irrigating with water from managed aquifer recharge (MAR) system as an alternate source in coastal areas. MAR for community water supply in saline areas is a project on supplying drinking water to the people in the coastal regions by mainly rain water harvesting which is carried out by the Department of Geology, University of Dhaka (and Acacia water, Netherlands). Here, water is collected from the nearby pond as well as rain water harvested from rooftop and pumped into 4 infiltration wells to a depth of $60 \mathrm{ft}$. A three layer filter is used and on top of which dense jute canvas is used. After filtering the water amount of salinity is markedly reduced.

\section{Materials and Methods}

The field experiment was set up at Gangarampur union of Batiaghata thana in Khulna district. Initial soil analysis by standard methods showed that the experimental field soil has a $\mathrm{pH}$ of 7.4, EC of $0.215 \mathrm{dS} / \mathrm{m}$ and contains $90 \mathrm{mg} / \mathrm{kg}$ available $\mathrm{N}$ with $1.09 \%$ organic carbon, $16 \mathrm{mg} / \mathrm{kg}$ available P, 7.36\% available K, 0.16\% available S, $12.86 \% \mathrm{Na}, 8.28 \% \mathrm{Ca}$ and $0.78 \% \mathrm{Mg}$.

Experiment was laid out in CBD with 3 replications i.e., whole experimental area was divided into 3 blocks, each block representing 1 replication. Unit plot size was $2.0 \mathrm{~m} \times 2.0 \mathrm{~m}$ and space between the plots, blocks and around the field was $1 \mathrm{~m}$. Total unit plot was 9 and total experimental area was $10 \mathrm{~m} \times 10 \mathrm{~m}$. Two types of water treatments were used in the experiment. One was saline water $\left(\mathrm{T}_{1}\right)$, which has been collected from the tube-well and second one was the treated water $\left(\mathrm{T}_{2}\right)$, which has been collected from MAR. Another observation was made considering the field condition of the plots which was considered as control $\left(\mathrm{T}_{0}\right)$ and no water was added from outside during the experiment in this treatment plot. Different physico-chemical properties of the treatment water were shown in Table 1.

Two treatments were distributed randomly in 6 plots and 3 plots were used to observe field condition (control). At the beginning of the experiment, the land was well prepared before sowing seed and no fertilizers were applied. Seeds of stem Amaranth were broadcasted on 28 March, 2014. After one week of sowing, stem Amaranth was germinated. Weeding and thinning was done as per requirement for the healthy growth of seedlings.

The plots were properly watered as per treatment. Amount of water applied to each field was uniform. As the field experiment was based on water treatment, rain water was not allowed to fall or seep to the $T_{1}$ and $T_{2}$ treatment plots. So, each plot was surrounded with aluminium sheet of 
$15 \mathrm{~cm}$ height and placed all around the plots. A bamboo made rain shed was used which was covered with a polythene sheet during the rain.

Table 1. Different physico-chemical properties of the treatment water.

\begin{tabular}{lccc}
\hline Properties & Control water $\left(\mathrm{T}_{0}\right)$ & Saline water $\left(\mathrm{T}_{1}\right)$ & Treated water $\left(\mathrm{T}_{2}\right)$ \\
\hline $\mathrm{pH}$ & 6.2 & 7.8 & 7.6 \\
$\mathrm{EC}(\mathrm{dS} / \mathrm{m})$ & 0.102 & 4.03 & 1.07 \\
$\mathrm{Na}(\mathrm{mg} / \mathrm{l})$ & 3.68 & 107.62 & 89.39 \\
$\mathrm{~K} "$ & 0.24 & 8.89 & 13.29 \\
$\mathrm{Ca} "$ & 0.58 & 54.05 & 65.34 \\
$\mathrm{Mg} \mathrm{"}$ & 0 & 30.04 & 28.48 \\
$\mathrm{Fe} \mathrm{"}$ & 0.2 & 1.345 & 0.135 \\
$\mathrm{Zn} \mathrm{"}$ & 0.001 & 0.199 & 0.02 \\
$\mathrm{Cu} "$ & 0 & 0 & 0 \\
$\mathrm{Mn} \mathrm{"}$ & 0.03 & 0.203 & 0.023 \\
\hline
\end{tabular}

The crop was harvested after 45 days of sowing. At the time of harvest, 5 plants from each plot was selected randomly and fresh weight of the plants, height, base diameter, dry weight of the plants were noted. Again, 20 plants were randomly collected from each plot and brought to the laboratory for analyzing nutrient uptake, nutrient composition and mineral content. In this study, the edible portion (leaf and stem) of plant samples were analyzed separately as per consumption pattern. Standard analytical methods were used to analyze soil and plant samples. Nutrient compositions of the plants were analyzed by following methods described by Raghuramulu et al. 2003. Statistical analysis was made by using SPSS (version 20).

\section{Results and Discussion}

Application of treatment showed significant effect on all the growth parameter like plant height, base diameter, fresh weight and dry weight (Table 2). From the table, it is observed that all the parameters were maximum for treated water $\left(\mathrm{T}_{2}\right)$ treatment. Again, lowest plant height and dry weight were observed for control $\left(\mathrm{T}_{0}\right)$ which was $34.3 \mathrm{~cm}$ and $3.3 \mathrm{t} / \mathrm{ha}$ and lowest base diameter and fresh weight were observed for saline water $\left(T_{1}\right)$ treatment which was $14.3 \mathrm{~mm}$ and $12.0 \mathrm{t} / \mathrm{ha}$.

The result of the experiment falls in line with the findings of Nerd et al. (1991) and Francois et al. (1990). Again, yield reduction in tomato fruit, lettuce and spinach was reported by Alam et al. (1989), Mizrahi and Pasternak (1985), Robinson et al. (1983).

Uptake of nutrients in Stem Amaranth plant was significant $(\mathrm{p}<0.05)$ in response to applied treatments. From the Table 3, it is visible that uptake of $\mathrm{N}$ and $\mathrm{P}$ is more for treated water $\left(\mathrm{T}_{2}\right)$ and less for saline water $\left(T_{1}\right)$. However, different results were found for $\mathrm{K}$ and $\mathrm{S}$ where highest uptake 
is obtained by control water $\left(\mathrm{T}_{0}\right)$ and lowest is by saline water $\left(\mathrm{T}_{1}\right)$ and treated water $\left(\mathrm{T}_{2}\right)$, respectively.

Table 2. Growth performance of stem Amaranth in response to different water treatments.

\begin{tabular}{lcccc}
\hline \multirow{2}{*}{ Treatment } & \multicolumn{4}{c}{ Stem Amaranth } \\
\cline { 2 - 5 } & $\begin{array}{c}\text { Plant height } \\
(\mathrm{cm})\end{array}$ & $\begin{array}{c}\text { Base diameter } \\
(\mathrm{mm})\end{array}$ & $\begin{array}{c}\text { Fresh weight } \\
(\mathrm{t} / \mathrm{ha})\end{array}$ & $\begin{array}{c}\text { Dry weight } \\
(\mathrm{t} / \mathrm{ha})\end{array}$ \\
\hline Control $\left(\mathrm{T}_{0}\right)$ & 34.3 & 16.0 & 15.6 & 3.3 \\
Saline $\left(\mathrm{T}_{1}\right)$ & 39.1 & 14.3 & 12.0 & 3.4 \\
Treated $\left(\mathrm{T}_{2}\right)$ & 51.7 & 19.4 & 23.0 & 4.6 \\
$\mathrm{p}<0.05$ & 0.000 & 0.000 & 0.000 & 0.000 \\
\hline
\end{tabular}

Table 3. Uptake of nutrients in stem Amaranth plant for different water treatments.

\begin{tabular}{lcccc}
\hline \multirow{2}{*}{ Treatment } & \multicolumn{5}{c}{ Kg/ha } \\
\cline { 2 - 5 } & $\mathrm{N}$ & $\mathrm{P}$ & $\mathrm{K}$ & $\mathrm{S}$ \\
\hline Control $\left(\mathrm{T}_{0}\right)$ & 3.50 & 33.66 & 572.88 & 51.15 \\
Saline $\left(\mathrm{T}_{1}\right)$ & 3.16 & 32.98 & 558.96 & 49.30 \\
Treated $\left(\mathrm{T}_{2}\right)$ & 3.54 & 39.56 & 564.42 & 48.76 \\
$\mathrm{p}<0.05$ & 0.000 & 0.000 & 0.000 & 0.000 \\
\hline
\end{tabular}

Table 4. Nutrient composition of Stem Amaranth (leaf) under different water treatments.

\begin{tabular}{lccccccc}
\hline \multirow{2}{*}{ Treatment } & $\begin{array}{c}\text { Soisture } \\
(\mathrm{g} / 100 \mathrm{~g})\end{array}$ & $\begin{array}{c}\text { Protein } \\
(\mathrm{g} / 100 \mathrm{~g})\end{array}$ & $\begin{array}{c}\text { Fat } \\
(\mathrm{g} / 100 \mathrm{~g})\end{array}$ & $\begin{array}{c}\text { Ash } \\
(\mathrm{g} / 100 \mathrm{~g})\end{array}$ & $\begin{array}{c}\text { TDF } \\
(\mathrm{g} / 100 \mathrm{~g})\end{array}$ & $\begin{array}{c}\text { Available } \\
\text { Carbohydrate } \\
(\mathrm{g} / 100 \mathrm{~g})\end{array}$ & $\begin{array}{c}\text { Energy } \\
(\text { Kcal/100 g) }\end{array}$ \\
\hline Control $\left(\mathrm{T}_{0}\right)$ & 79.88 & 3.97 & 1.24 & 3.41 & 5.59 & 5.91 & 61.86 \\
Saline $\left(\mathrm{T}_{1}\right)$ & 80.16 & 4.32 & 1.09 & 3.71 & 5.64 & 5.09 & 58.70 \\
Treated $\left(\mathrm{T}_{2}\right)$ & 80.14 & 3.16 & 0.46 & 3.26 & 6.87 & 6.09 & 54.94 \\
$\mathrm{p}<0.05$ & $\mathrm{NS}$ & 0.000 & 0.000 & 0.000 & 0.000 & $\mathrm{NS}$ & $\mathrm{NS}$ \\
\hline
\end{tabular}

*NS= Not significant.

The moisture content in leaf ranges from $80.16 \mathrm{~g} / 100 \mathrm{~g}$ to $79.88 \mathrm{~g} / 100 \mathrm{~g}$ and in stem from $90.07 \mathrm{~g} / 100 \mathrm{~g}$ to $89.49 \mathrm{~g} / 100 \mathrm{~g}$ for different treatments. There was no significant difference in moisture content between the treatments.

The protein, fat and ash content of the plant decreases for $\mathrm{T}_{2}$ treatment for both leaf (3.16, 0.46 and $3.26 \mathrm{~g} / 100 \mathrm{~g})$ and stem $(0.67,0.21,1.79 \mathrm{~g} / 100 \mathrm{~g})$ (Tables 4 and 5). The imbalance caused by salinity affects the nutrients involved in protein synthesis and those involved in photosynthesis, which can lead to inhibition of these processes (Vieira-Santos et al. 2001). One characteristic of saline stress is the removal of potassium ions by plant roots, which causes a physiological imbalance because potassium is necessary for protein synthesis. Kuiper (1968) found that the content of lipids increased with increasing capacity for uptake of chloride and salt tolerance. The 
salt tolerance of the oil producing plants as well as the enhancements in their activities after being salinized appeared to be a general feature of the oil producing plants may strengthen the impression that these plants may have their own mechanisms to counteract at least the effect of mild salinization treatments. This mechanism could be coordinated with the biosynthesis of fats or

Table 5. Nutrient composition of stem Amaranth (stem) under different water treatments.

\begin{tabular}{lccccccc}
\hline & \multicolumn{7}{c}{ Stem Amaranth (stem) } \\
\cline { 2 - 8 } Treatment & $\begin{array}{c}\text { Moisture } \\
(\mathrm{g} / 100 \mathrm{~g})\end{array}$ & $\begin{array}{c}\text { Protein } \\
(\mathrm{g} / 100 \mathrm{~g})\end{array}$ & $\begin{array}{c}\text { Fat } \\
(\mathrm{g} / 100 \mathrm{~g})\end{array}$ & $\begin{array}{c}\text { Ash } \\
(\mathrm{g} / 100 \mathrm{~g})\end{array}$ & $\begin{array}{c}\text { TDF } \\
(\mathrm{g} / 100 \mathrm{~g})\end{array}$ & $\begin{array}{c}\text { Available } \\
\text { carbohydrate } \\
(\mathrm{g} / 100 \mathrm{~g})\end{array}$ & $\begin{array}{c}\text { Energy } \\
(\text { Kcal/100 g) }\end{array}$ \\
\hline $\begin{array}{l}\text { Control } \\
\left(\mathrm{T}_{0}\right)\end{array}$ & 89.49 & 0.83 & 0.24 & 2.29 & 3.95 & 3.2 & 26.18 \\
$\begin{array}{l}\text { Saline }\left(\mathrm{T}_{1}\right) \\
\begin{array}{l}\text { Treated } \\
\left(\mathrm{T}_{2}\right)\end{array}\end{array}$ & 90.07 & 0.88 & 0.28 & 2.06 & 3.76 & 2.96 & 25.37 \\
$\mathrm{p}<0.05$ & 90.66 & 0.67 & 0.21 & 1.79 & 3.12 & 3.55 & 25.04 \\
\hline
\end{tabular}

*NS= Not significant.

Table 6. Mineral content of stem Amaranth (leaf) under different water treatments.

\begin{tabular}{lllllllll}
\hline \multirow{2}{*}{ Treatment } & \multicolumn{7}{c}{ Stem Amaranth (leaf) (mg/100 g) } \\
\cline { 2 - 9 } & $\mathrm{Na}$ & $\mathrm{K}$ & $\mathrm{Ca}$ & $\mathrm{Mg}$ & $\mathrm{Fe}$ & $\mathrm{Zn}$ & $\mathrm{Cu}$ & $\mathrm{Mn}$ \\
\hline Control $\left(\mathrm{T}_{0}\right)$ & 934.12 & 321 & 515 & 880 & 76.5 & 9.0 & 1.95 & 2.8 \\
Saline $\left(\mathrm{T}_{1}\right)$ & 139.12 & 341 & 785 & 1125 & 48.5 & 10.5 & 2.20 & 3.35 \\
Treated $\left(\mathrm{T}_{2}\right)$ & 72.87 & 368 & 825 & 805 & 46.0 & 9.0 & 1.30 & 2.15 \\
$\mathrm{p}<0.05$ & 0.000 & 0.000 & 0.000 & 0.000 & 0.000 & 0.013 & 0.003 & 0.000 \\
FCTB Value & 36 & 321 & 171 & 181 & 8.4 & 0.98 & 0.12 & $\mathrm{NA}$ \\
\hline
\end{tabular}

*NA= Not available.

a certain fat fraction. Ash represents the total inorganic mineral present in the plant. In saline condition uptake of salt is higher than the treated one. The TDF of plant ranges from $6.87 \mathrm{~g} / 100 \mathrm{~g}$ to $5.59 \mathrm{~g} / 100 \mathrm{~g}$ in leaf and $3.95 \mathrm{~g} / 100 \mathrm{~g}$ to $3.12 \mathrm{~g} / 100 \mathrm{~g}$ in stem for different treatments. Again, it can be observed that, highest TDF in leaf is due to treated water $\left(\mathrm{T}_{2}\right)$ and lowest TDF is for control water $\left(\mathrm{T}_{0}\right)$, while for stem, more TDF is found for control water $\left(\mathrm{T}_{0}\right)$ and less TDF is in case of the induced treatment $\left(\mathrm{T}_{2}\right)$. The available carbohydrate content in leaf and stem ranges from 6.09 $\mathrm{g} / 100 \mathrm{~g}$ to $5.09 \mathrm{~g} / 100 \mathrm{~g}$ and $3.55 \mathrm{~g} / 100 \mathrm{~g}$ to $2.96 \mathrm{~g} / 100 \mathrm{~g}$ in stem for various treatments. From the Tables 3 and 4, it can be observed that, carbohydrate content both for leaf and stem were found to be $\mathrm{T}_{2}>\mathrm{T}_{0}>\mathrm{T}_{1}$. Many plants stressed by $\mathrm{NaCl}$ salinity, accumulated starch and soluble carbohydrates (Rathert 1984). This accumulation has been attributed to impaired carbohydrate utilization (Munns and Termaat 1986). But it is apparent from the results that the carbohydrate content in the leaves was higher in treated plants compared with saline. While for the energy of the plant ranges from lowest to highest for $\left(T_{2}<T_{1}<T_{0}\right)$ treatments. Opposite result was found by Heidari and Jamshid (2010). 
The mineral content ( $\mathrm{Na}, \mathrm{K}, \mathrm{Ca}, \mathrm{Mg}, \mathrm{Fe}, \mathrm{Zn}, \mathrm{Cu}, \mathrm{Mn}$ ) of the stem Amaranth varies significantly with different water treatments (Tables 6 and 7). The Na content in the leaf of the stem Amaranth plant was 934.12, 139.12, and $72.87 \mathrm{mg} / 100 \mathrm{~g}$ and in the stem were 685.68, 669.12, and $205.37 \mathrm{mg} / 100 \mathrm{~g}$. Na content is drastically reduced both for leaf and stem with treated water than the other two water treatments.

Table 7. Mineral content of stem Amaranth (stem) under different water treatments.

\begin{tabular}{lllllllll}
\hline \multirow{2}{*}{ Treatment } & \multicolumn{7}{c}{ Stem Amaranth (stem) (mg/100g) } \\
\cline { 2 - 9 } & $\mathrm{Na}$ & $\mathrm{K}$ & $\mathrm{Ca}$ & $\mathrm{Mg}$ & $\mathrm{Fe}$ & $\mathrm{Zn}$ & $\mathrm{Cu}$ & $\mathrm{Mn}$ \\
\hline Control $\left(\mathrm{T}_{0}\right)$ & 685.68 & 778 & 310 & 790 & 14.0 & 2.5 & 3.15 & 1.0 \\
Saline $\left(\mathrm{T}_{1}\right)$ & 669.12 & 827 & 375 & 580 & 39.5 & 10.0 & 1.25 & 0.75 \\
Treated $\left(\mathrm{T}_{2}\right)$ & 205.37 & 408 & 295 & 425 & 33.5 & 6.0 & 1.35 & 0.75 \\
$\mathrm{p}<0.05$ & 0.000 & 0.000 & 0.000 & 0.000 & 0.000 & 0.000 & 0.000 & 0.004 \\
FCTB Value & NA & NA & 114 & NA & 1.8 & 0.52 & NA & NA \\
\hline
\end{tabular}

*NA= Not available.

The higher amount of Na was found in the leaf in control condition might be due to lesser amount of rainfall during the growth period, and accumulated salt was taken up by the roots and biomagnification takes place. The greater aptitude of basal leaves to accumulate sodium, as a result of increasing the level of $\mathrm{NaCl}$ in the root environment, could be related to water transpired by the leaves because $\mathrm{Na}^{+}$is transported to shoots in the transpiration stream in the xylem (Munns and Tester 2008). The K content of the Stem Amaranth plant ranges from 321 to $368 \mathrm{mg} / 100 \mathrm{~g}$ in the leaf and from 408 to $827 \mathrm{mg} / 100 \mathrm{~g}$ in stem. Chow et al. (1990) observed that lower salinity stimulated growth while higher salinity reduced growth and also $\mathrm{K}^{+}$up take in the leaves of spinach. They suggested that higher $\mathrm{K}^{+}$content was required for shoot growth under higher salinity. On the other hand, higher concentration of $\mathrm{Na}^{+}$was required to maintain turgor pressure under salinity, but it could not substitute $\mathrm{K}^{+}$requirement. The Ca content in the leaf of the stem Amaranth plant was 515, 785, and $825 \mathrm{mg} / 100 \mathrm{~g}$ and in the stem 310, 375, and $295 \mathrm{mg} / 100 \mathrm{~g}$. In presence of high concentration of salts, $\mathrm{Ca}^{2+}$ plays an important role in the maintenance of $\mathrm{K}^{+}$ transport (Sopandie et al. 1990). It was also observed that $\mathrm{Ca}^{2+}$ and $\mathrm{K}^{+}$compete with each other in the absence of $\mathrm{Na}^{+}$. Again, in presence of $\mathrm{Ca}^{2+}$, potassium uptake increased under high $\mathrm{NaCl}$ concentration. The Mg content in the leaf of the stem Amaranth plant was 880, 1125, and 805 $\mathrm{mg} / 100 \mathrm{~g}$ and in the stem 790, 580, and $425 \mathrm{mg} / 100 \mathrm{~g}$. Epstein (1961) reported that presence of $\mathrm{Ca}^{2+}$ in saline solution is essential for $\mathrm{K}^{+}$selectivity. He also reported that $\mathrm{Mg}^{2+}$ could not be substituted for $\mathrm{Ca}^{2+}$ under salinity condition. The Fe content of the stem Amaranth plant ranges from 76.5 to $46 \mathrm{mg} / 100 \mathrm{~g}$ in leaf and 39.5 to $14 \mathrm{mg} / 100 \mathrm{~g}$ in stem. The Zn content in the leaf was 9, 10.5, and $9 \mathrm{mg} / 100 \mathrm{~g}$ and in the stem 2.5, 10, and $6 \mathrm{mg} / 100 \mathrm{~g}$. While the Cu content in the leaf of the stem Amaranth plant was 1.95, 2.2, and $1.3 \mathrm{mg} / 100 \mathrm{~g}$ and in the stem $3.15,1.25$, and 1.35 $\mathrm{mg} / 100 \mathrm{~g}$. The Mn content in the leaf was $2.8,3.35$, and $2.15 \mathrm{mg} / 100 \mathrm{~g}$ and in the stem 1, 0.75, and $0.75 \mathrm{mg} / 100 \mathrm{~g}$. According to the food composition table for Bangladesh (FCTB) (2013) the 
average mineral content was shown in the Tables 6 and 7, and it can be seen that the values for treated plants improve around the values found for general plants.

During investigation, there were no appreciable changes in soil $\mathrm{pH}$ for different treatments, but there was a tendency of rising $\mathrm{pH}$ values due to irrigating with saline water (7.73). After harvesting of stem Amaranth, EC (0.115 dS/m), organic carbon (0.47 \%), K (4.83\%), Na (8.99\%), Ca (6.03\%) and $\mathrm{Mg}(0.55 \%)$ content decreased more for treated water $\left(\mathrm{T}_{2}\right)$ treatment. However, $\mathrm{N}$ (12 mg/kg) and $\mathrm{P}$ content $(25 \mathrm{mg} / \mathrm{kg})$ decreased more for saline water $\left(\mathrm{T}_{1}\right)$ treatment. After harvesting $\mathrm{S}$ content of the surface soil decreases $(750 \mathrm{mg} / \mathrm{kg})$ for control water $\left(\mathrm{T}_{0}\right)$ and increases $(2300 \mathrm{mg} / \mathrm{kg})$ for treated water $\left(\mathrm{T}_{2}\right)$.

\section{Summary and Conclusion}

The effect of saline water $\left(\mathrm{T}_{1}\right)$ and treated water $\left(\mathrm{T}_{2}\right)$ irrigation on plant height, base diameter, fresh weight and dry weight showed a significant variation at 5\% level. All the growth parameters improved for treated water $\left(T_{2}\right)$ than for saline water $\left(T_{1}\right)$. Response of treated water $\left(T_{2}\right)$ is much better than saline water $\left(T_{1}\right)$ in relation to nutrient composition. Carbohydrate and total dietary fiber (TDF) is increased while protein, fat, ash and energy in the leaf of stem Amaranth are decreased by irrigating with $T_{2}$ water. Moreover, carbohydrate content is increased in treated water $\left(\mathrm{T}_{2}\right)$ but protein, fat, ash, TDF and energy in the stem of stem Amaranth is decreased. Na, $\mathrm{Mg}, \mathrm{Fe}$ and $\mathrm{Zn}$ content increased both in leaf and stem for treated water, whereas, $\mathrm{K}$ and $\mathrm{Ca}$ increased in leaf but decreased in stem. Available N, P, and S of soil were increased in the Stem Amaranth plot by irrigating it with treated water $\left(\mathrm{T}_{2}\right)$ but $\mathrm{EC}, \mathrm{pH}, \mathrm{K}, \mathrm{Na}, \mathrm{Ca}$, and $\mathrm{Mg}$ are decreased markedly. From the study, it is found that the best alternate water source is treated water (MAR water) for better food production as well as good quality crops and balanced nutrition in food. This effort will play a vital role in bringing the huge saline land under cultivation and also in full filling the nutritional requirement of the poorer and under privileged people.

\section{Acknowledgement}

The authors thank Managed Aquifer Recharge (MAR) for community water supply in saline areas, Khulna district for supporting to conduct the field experiment and assisting in soil and plant sampling, and finally for their logistic support. Also thanks to Dr. Kazi Matin Uddin Ahmed, Professor, Department of Geology, University of Dhaka for his help and support, guidance and suggestion during the field work in Khulna.

\section{References}

Alam, S.M., S.S.M. Naqvi and A.R. Azmi. 1989. Effect of salt stress on growth of tomato. Pakistan Journal of Scientific and Industrial Research 32(2): 110-113.

Chow, W.S., M.C. Ball and J.M. Anderson. 1990. Growth and photosynthetic responses of spinach to salinity: Implications of $\mathrm{K}^{+}$nutrition for salt tolerance. Australian Journal of Plant Physiology. 17: 563-578. 
Epstein, E. 1961. The essential role of calcium in selective cation transport by plant cells. Plant Physiology 36: 437-444.

FCTB (Food Composition Table for Bangladesh), 2013. Institute of Nutrition and Food Science and Centre for Advanced Research in science, University of Dhaka. Intergraphic limited, Segun Bagicha, Dhaka1000, Bangladesh. pp. 21-34.

Francois, L.E., T.J. Donovan and E.V. Mass. 1990. Salinity effects on emergence, vegetative growth and seed yield of guar. Agronomy Journal 82: 587-592.

Haque, S.A. 2006. Salinity Problem and Crop Production in Coastal Regions of Bangladesh Pakistan Journal of Botany 38(5): 1359-1365.

Heidari, M. and P. Jamshid. 2010. Interaction between salinity and potassium on grain yield, carbohydrate content and nutrient uptake in pearl millet. Journal of Agricultural Biological Science 5(6): 39-46.

Karim, Z., S.M. Saheed, A.B.M. Salauddin, M.K. Alam and A. Huq. 1982. Coastal saline soils and their management in Bangladesh. Bangladesh Agricultural Research Council 8: 33.

Karim, Z., S.G. Hussain and M. Ahmed. 1990. Salinity Problems and Crop Intensification in the Coastal Regions of Bangladesh. Bangladesh Agricultural Research Council 33: 63.

Kuiper, P.J.C. 1968. Lipids in grape roots in relation to chloride transport. Plant Physiology 43: 1367-1371.

Mizrahi, Y. and D. Pasternak. 1985. Effects of salinity on quality of various agricultural crops. Plant and Soil Journal 89(1-3): 301-307.

Munns, R. and A. Termaat. 1986. Whole plant responses to salinity. Australian Journal on Plant Physiology 13: $143-160$.

Munns, R. and M. Tester. 2008. Mechanisms of salinity tolerance. Annual Review of Plant Biology 59: 651-681.

Nerd, A., A. Karadi and Y. Mizrahi. 1991. Salt tolerance of prickly pear cactus (Opuntia ficus indica). Journal on Plant and Soil 137: 201-207.

Raghuramulu, N., N.K. Madhavan and S. Kalyanasundaram. 2003. A Manual of Laboratory Techniques. National Institute of Nutrition.Indian Council of Medical Research, Hyderabad, India. pp. 56-58.

Rathert, G. 1984. Sucrose and starch content of plant parts as a possible indicator for salt tolerance of crops. Australian Journal on Plant Physiology 11: 491-495.

Robinson, S.P., W.J. Downtown and J. Milkowse. 1983. Photosynthesis and ion content of leaves and isolated chloroplasts of salt stressed spinach. Plant Physiology 12: 471-479.

Sopandie, D., M. Moritsugu and T. Kawasaki. 1990. Interactions between calcium, sodium and potassium in Salicornia virginica and barley roots under saline conditions: Multicompartment transport box experiments. Journal of Soil Science and Plant Nutrition 36(1): 65-72.

Vieira Santos, C.L., A. Campos, H. Azevedo and G. Caldeira. 2001. In situ and in vitro senescene induced by $\mathrm{KCl}$ stress: Nutritional imbalance, lipid peroxidation and antioxidant metabolism. Journal of Experimental Botany 52: 351-360.

(Manuscript received on 13 July, 2015; revised on 01 September, 2015) 